belong to multiple sections and present multiple papers at a meeting, as men do, and have little time for anything else. This would be a resource problem that limits female participation in LSS activities.

Third, how many women submit papers to $L S Q$ ? The publication rate suggests that women are far less likely than men to gain acceptance to the journal: $18 \%$ solo female authors compared to $59 \%$ solo male authors and $23 \%$ authors of both sexes. Stated another way, female authors are present in $41 \%$ of articles and male authors in $82 \%$. It seems unlikely that the women who have served as recent editors of the journal have actively discriminated against female authors or that a blind review process has winnowed out women in favor of men. However, I am guessing that the majority of reviewers for $L S Q$ are male. If the acceptance rate for women is lower than for men, perhaps it arises from an epistemological problem in which the dominant group in our field applies criteria about scholarly merit that inadvertently disadvantages women.

Fourth, legislative studies cut across a variety of subfields in American politics, as well as comparative politics. As the number of APSA sections proliferates, scholars who study congressional elections, for example, might see their intellectual home in organizations devoted to political campaigns or voting behavior, whereas those who examine policy outcomes might prefer to focus on parliamentary systems. Perhaps scholars who are interested in broad issues of representation and democratic accountability have found more fruitful terrain in other parts of the world. After all, the US Congress-which is the focus of so many legislative scholars-is highly unusual in the universe of legislative institutions. This would lead to an ethnocentric problem in which the dominance of congressional scholars in our subfield deters others from engaging in the section.

From my vantage point of 40-plus years as an LSS member, I would say that recruitment, resources, epistemology, and the bias of our subfield toward Congress are recurring problems. Moreover, legislative studies have never had the lure for budding political scientists that other subfields in American politics enjoy. Furthermore, with public approval of Congress at an historically low ebb and the institution barely able to function, we should not be surprised that our section is having difficulty attracting active members. What remains perplexing to me is why any of these factors would disproportionately affect women and what the section might do to improve. Although the numbers at this point seem troubling, I would need more context before attempting to devise a strategy to address them.

Nevertheless, I had hoped that issues of gender equity in the profession would have faded by now. My personal experience in the profession differed greatly from what women experience today. I was, for example, the only female member of my graduateschool class at the University of Rochester (Barbara Sinclair had finished and Lynda Powell was several years ahead of me); the first female tenure-track hire in my department and the first woman tenured in that department; the only female member of the founding editorial board for $L S Q$; and the first female chair of the LSS. I remember exhausting days in which I was the only woman in the elevator at APSA conventions; a lone female adrift in a sea of blue blazers and khaki trousers at the Palmer House; and a solitary individual eating in my room because I feared sending the wrong signal if I invited myself to dinner with the boys.
I also was incredibly fortunate. Dick Fenno, my mentor and friend, created a bond among his former students through their respect and affection for him. He also fostered an exceptional community among legislative scholars: if you were interested in Congress or state legislatures, then you were in. Thanks to his example and others (e.g., Pat Patterson, Chuck Jones, Mac Jewell, and Jerry Loewenberg), the study of Congress was wide open to all types of methodologies from "soaking and poking," to formal theories of legislative bodies, to the mining of historical data to test explanations of institutional development. I had found when I was employed at the newly formed Environmental Protection Agency in 1970 that gender mattered less when there was work to be done on a brand-new agenda, and I think a similar ethos prevailed in the early days of the LSS.

Perhaps the issue today is not gender bias per se but rather the fact that our subfield is too settled. Legislative studies, in my view, has become focused on increasingly narrow questions and guarded by rigid norms about what counts as evidence. The articles in our journal look remarkably alike with the primary difference being the labels on the $\mathrm{X}$ and $\mathrm{Y}$ axes. Established people have turf to protect while good jobs in the academy are generally scarce. Such a climate does not foster acceptance for newcomers. Indeed, I have had many conversations with young male scholars in recent years who find the LSS less than welcoming.

Moreover, anyone can see that women are present at conferences and hold positions of leadership in substantial numbers. Some observers might conclude, therefore, that the LSS is doing fine. Is there parity? No. Do I still feel like an interloper at meetings? Yes. Am I surprised that some male colleagues-who have professional wives or female partners and friends and presumably should know better-still seem as clueless as Bill Riker when he queried my game-theory class by asking what value to ascribe to the certain option in a lottery between Miss Fowler and a lightbulb? You bet.

Women in legislative studies today contend with different obstacles than those I encountered. Bias is more subtle and therefore more difficult to call out. In addition, expectations among women entering our profession have changed-and rightly so. Barbara Sinclair and I sometimes joked that professional slights or outright hostility were less wounding for us than our younger colleagues because we never expected anything else. Yet, comparatively speaking, I would say the glass still seems half full rather than half empty-and I believe Barbara would probably have agreed.

\section{HOW DO WE GET MORE WOMEN TO STUDY LEGISLATIVE POLITICS?}

\section{Michele Swers, Georgetown University}

\section{DOI: $10.1017 / S_{1049096519002099}$}

As a scholar who studies women and Congress, when I was invited to write for this issue, I was struck by the fact that the proportion of women in the Legislative Studies Section (LSS), $22 \%$, closely mirrors the proportion of women in Congress. According to the Center for American Women and Politics (2019), women constitute $23.6 \%$ of the 116th Congress (2019-2020). Thus, women's standing in the section is comparable to other high-status fields, 
from Congress to law-firm partnerships that require advanced credentials and long hours and reflect a set of institutional norms that were developed largely by men over a long period of time. Like other institutions, the advancement of more women into the field will require openness to change and investment in mentoring and recruitment.

Studying descriptive representation, I occupy multiple fields working with both legislative scholars and women and politics scholars. As a result, I inhabit spaces that are predominantly male and spaces that are largely female. Going to graduate school at Harvard in the late 1990s, I was the only woman studying American politics in my entering cohort. There were a few women in the cohorts ahead of me and they were early mentors. When I started my job at Georgetown in 2002, I was again the only woman in the American politics field; that remained true until relatively recently. However, in the Washington, DC, area, several women study legislative politics, including Sarah Binder, Frances Lee, Jennifer Victor, Colleen Shogan, Molly Reynolds, Stella Rouse, Kris Miller, Anne Marie Cammisa, Marian Currinder, and many others. Thus, although I have generally been a minority in rooms of legislative scholars, I have never felt alone.

When I first started going to political science conferences, there were few women on the panels and roundtables. I particularly admired Barbara Sinclair. Her books on the Senate and the evolution of the parties in Congress strongly influenced my outside of my usual networks and contact people I did not know to attract a broader set of candidates. When organizing a conference or panel, we need to move beyond what is comfortable and recruit a mix of younger and older scholars, men and women, racial and ethnic minorities. A conference with more diverse perspectives will broaden our networks and make for a more interesting dialogue.

Another area that we should focus on is mentoring. No one achieves success in political science without guidance from mentors along the way. I have benefited from the advice of male and female mentors throughout my career. These mentors have connected me to other scholars and interview subjects for my research. They have read my work, shared data, and offered helpful comments and advice. They have invited me to conferences that sparked ideas and have asked me to contribute to edited volumes that brought my work to new audiences. As a young scholar, the scariest and most important thing one can do is ask. Invite a scholar you want to connect with for coffee or to a brief meeting at APSA to discuss their work and how it influences yours. Attend an LSS business meeting and/or reception and strike up a conversation with someone whose work interests you. Approach the author of a conference paper after the panel ends. Make yourself known and send a thank-you email to build the relationship. Established scholars need to be open to expanding their networks and building new relationships to foster young talent.

\section{Invite a scholar you want to connect with for coffee or to a brief meeting at APSA to discuss their work and how it influences yours.}

thinking about institutional norms, partisan polarization, and how gender might interact with partisanship and other incentives that shape legislative behavior. If she was listed as a presenter, I always tried to attend that panel. She was the rock star I most admired, and when she spoke to me once in an elevator, I felt like I had met Barbra Streisand.

Although many more women attend conferences and present on panels today, we remain a minority in the field. When I present on a legislative panel or attend a specialized conference or workshop, there usually are more men than women in the room. By contrast, when I present on a panel sponsored or cosponsored by the Women and Politics Section or attend a specialized conference on descriptive representation or women candidates, the audience is almost exclusively women. Both fields could benefit from more gender balance.

To welcome more women into legislative studies, I think the field must focus more intentionally on recruitment and mentoring. With regard to recruitment, I encourage those who are organizing specialized conferences and the section chairs who select the papers for panels to include more women as panelists, discussants, and chairs. Our networks tend to be small, developed in graduate school and from years of attending the same conferences and panels. By reaching out to who we know, we perpetuate that insular cycle. When I recently chaired several job-search committees for my department, I realized that to recruit a more diverse pool of applicants, I needed to reach
Finally, if we want to broaden the audience for our work, we must expand the range of articles considered for publication in our journals. When submitting work or being asked to review, I am always struck by the question, "Will this work be of interest or suitable for readers of X journal?" One thing that likely prevents more women from publishing in journals is the tendency to silo ourselves into specific outlets. Studies that focus on gender and legislatures should not be routinely funneled to specialized gender outlets, just as work on state legislatures should not be assumed to be of interest only to readers of State Politics and Policy Quarterly. Legislative scholars will benefit from reading more work on a variety of topics that utilizes a mix of methodologies.

By implementing these recommendations, the legislative field can increase the membership of women beyond the proportions in Congress and aspire to be more like Colorado and Oregon, which have more than $40 \%$ women in their state legislatures, or even the Nevada Assembly (i.e., the lower house), which now has an equal number of men and women, demonstrating that gender parity is within reach (Gonzalez 2018).

\section{REFERENCES}

Center for American Women and Politics. 2019. "Women in Elective Office 2019." New Brunswick, NJ: Rutgers University, Center for American Women in Politics, Eagleton Institute of Politics.

Gonzalez, Yvonne. 2018. "Democrats Solidify Their Majorities at the Legislature." Las Vegas Sun, November 11. 